\title{
POTRET KEMISKINAN KOTA PADANG MENGGUNAKAN METODE WAJAH CHERNOFF
}

\author{
Rini Eka Putri, Hazmira Yozza, Izzati Rahmi HG \\ Program Studi Matematika, \\ Fakultas Matematika dan Ilmu Pengetahuan Alam, Universitas Andalas, \\ Kampus UNAND Limau Manis Padang, Indonesia. \\ email : putririnieka29@yahoo.com
}

\begin{abstract}
Abstrak. Metode Wajah Chernoff merupakan suatu upaya untuk merepresentasi data peubah ganda dalam bentuk wajah kartun dengan 20 ciri wajah spesifik. Pada penelitian ini ditunjukkan bagaimana metode wajah Chernoff digunakan untuk melihat potret kemiskinan Kota Padang. Untuk memasangkan ciri wajah Chernoff dengan indikator kemiskinan, maka dilakukan survei peringkat ciri wajah dan Analisis Komponen Utama. Dari 15 indikator kemiskinan Kota Padang, terdapat lima indikator di bawah rata-rata, empat indikator di atas rata-rata, dan selainnya di sekitar rata-rata. Dari 11 wajah Chernoff kecamatan Kota Padang, terdapat empat kandidat kecamatan dengan wajah Chernoff relatif tidak bagus yaitu kecamatan Bungus Teluk Kabung, kecamatan Koto Tangah, kecamatan Lubuk Kilangan, dan kecamatan Padang Selatan; lima kandidat kecamatan dengan wajah Chernoff relatif bagus yaitu kecamatan Padang Barat, kecamatan Padang Utara, kecamatan Nanggalo, kecamatan Lubuk Begalung, dan kecamatan Padang Timur.
\end{abstract}

Kata Kunci: Indikator kemiskinan, Analisis Komponen Utama, Metode wajah Chernoff

\section{Pendahuluan}

Kemiskinan merupakan salah satu masalah yang dihadapi Indonesia sejak dulu hingga sekarang, apalagi sejak terhempasnya oleh pukulan krisis ekonomi dan moneter sejak tahun 1997. Kota Padang merupakan salah satu daerah yang tingkat kemiskinannya cukup tinggi. Angka kemiskinan Kota Padang pada tahun 2011 sebesar 20,23 persen [2]. Melalui beberapa program yang berkelanjutan pemerintah Kota Padang terus berupaya menanggulangi kemiskinan. Peranan data kemiskinan menjadi sangat penting dalam keberhasilan pelaksanaan program tersebut. Berbagai definisi dan indikator untuk mengukur tingkat kemiskinan dan menghitung jumlah penduduk miskin telah diformulasikan dan dikembangkan, dengan harapan upaya pengentasan kemiskinan akan lebih tepat sasaran. Informasi indikator kemiskinan dari Badan Pusat Statistik diperoleh melalui pendataan ulang kemiskinan tahun 2011. Saat ini, informasi indikator kemiskinan disajikan dalam bentuk ulasan, tabel, diagram batang dan pie chart, terpisah untuk masing-masing indikator kemiskinan. Akan menjadi lebih informatif jika indikator-indikator tersebut bukan hanya disajikan dalam bentuk ulasan, tabel, diagram batang dan pie chart, tetapi disajikan dalam suatu tampilan grafis peubah ganda yaitu salah satunya metode wajah Chernoff. Dengan menggunakan tampilan wajah Chernoff maka informasi dapat diko- 
munikasikan secara ekspresif, mudah diingat, dan menarik untuk dilihat.

Metode wajah Chernoff pertama kali diperkenalkan oleh Herman Chernoff pada tahun 1973 dan sejak saat itu metode ini terus berkembang dan menjadi salah satu alat eksplorasi data peubah ganda secara grafis yang bisa digunakan untuk mendeteksi adanya pencilan atau pengelompokkan objek [3].

Dalam penelitian ini, peneliti menyajikan dan mendeskripsikan bagaimana tampilan visual potret kemiskinan Kota Padang dalam bentuk wajah Chernoff.

\section{Data dan Metode Penelitian}

Jenis data yang digunakan adalah data sekunder yang diperoleh dari hasil pendataan ulang kemiskinan tahun 2011. Sumber data yang lain adalah data primer yang diperoleh dengan menggunakan metode survei, yaitu penyebaran kuesioner kepada 30 orang mahasiswa Matematika FMIPA UNAND.

Pada penelitian ini digunakan 15 indikator kemiskinan dari Badan Pusat Statistik [1] sebagai berikut.

$X_{1}$ : Persentase Kepala Rumah Tangga yang tidak punya ijazah (\%),

$X_{2}$ : Persentase Kepala Rumah Tangga yang tamat SD/SMP sederajat (\%),

$X_{3}$ : Persentase Rumah Tangga dengan status penguasaan bangunan tempat tinggal kontrak/sewa (\%),

$X_{4}$ : Persentase Rumah Tangga dengan status penguasaan bangunan tempat tinggal milik sendiri (\%),

$X_{5}$ : Persentase Kepala Rumah Tangga yang tamat SMA/sederajat (\%),

$X_{6}$ : Persentase Rumah Tangga dengan jenis atap seng (\%),

$X_{7}$ : Persentase Rumah Tangga dengan jenis atap ijuk/rumbai (\%),

$X_{8}$ : Persentase Rumah Tangga dengan dinding kayu (\%),

$X_{9}$ : Persentase Rumah Tangga dengan jenis lantai tanah (\%).

$X_{10}$ : Persentase Rumah Tangga dengan sumber air minum dari air tak terlindung (\%),

$X_{11}$ : Persentase Rumah Tangga yang tidak ada listrik (\%),

$X_{12}$ : Persentase Rumah Tangga dengan fasilitas tempat BAB bersama/umum (\%),

$X_{13}$ : Persentase Rumah Tangga dengan kondisi kesejahteraan sampai dengan $10 \%$ terendah (\%),

$X_{14}$ : Persentase Rumah Tangga dengan kondisi kesejahteraan antara $11 \%$ - 20\% terendah (\%),

$X_{15}$ : Persentase Rumah Tangga dengan kondisi kesejahteraan antara $21 \%-30 \%$ terendah (\%).

Perancangan wajah Chernoff dilakukan dengan cara memasangkan indikatorindikator kemiskinan dengan ciri-ciri wajah Chernoff sebagai berikut.

(1) Mengadakan survei tentang ciri wajah Chernoff dengan cara menyebar kuesioner kepada 30 responden. Dari hasil survei ini akan diperoleh gambaran mengenai ciri-ciri wajah mana yang paling mampu menggambarkan perbedaan beberapa wajah Chernoff.

(2) Menggunakan Analisis Komponen Utama (AKU)

Berdasarkan hasil dari AKU, diperoleh peubah baru $Y_{1}, Y_{2}, \cdots, Y_{15}$ yang merupakan kombinasi linear dari $X_{i}$. Setelah diperoleh peubah baru $Y_{1}, Y_{2}, \cdots, Y_{15}$, 
langkah selanjutnya yaitu mencari harga mutlak koefisien terbesar dari $X_{i}$ pada masing-masing $Y_{i}$ yang diperoleh.

(3) Memasangkan peubah $X_{i}$ yang telah dicari harga mutlak koefisien terbesar dengan hasil survei terhadap ciri wajah Chernoff, sehingga peubah yang penting akan diwakili oleh ciri-ciri wajah yang paling mampu dalam menggambarkan perbedaan potret kemiskinan pada kecamatan di Kota Padang.

\section{Hasil dan Pembahasan}

Berdasarkan hasil survei, didapatkan peringkat ciri wajah Chernoff sebagai berikut : Kelengkungan Mulut, Kemiringan Alis, Tinggi Alis, Posisi Pupil, Kemiringan Mata, Bentuk Elips Mata, Panjang Mulut, Jarak Antar Mata, Panjang Hidung, Posisi Pusat Mulut, Tinggi Pusat Mata, Lebar Wajah, Bentuk Elips Bawah Wajah, Bentuk Elips Atas Wajah, Panjang Alis, Setengah Tinggi Wajah, Lebar Hidung, Setengah Panjang Mata, Posisi Telinga, Jari-Jari Telinga. Karena dalam penelitian ini digunakan 15 ciri wajah Chernoff, maka lima peringkat terbawah yaitu Setengah Tinggi Wajah, Lebar Hidung, Setengah Panjang Mata, Posisi Telinga, dan Jari-jari Telinga tidak dipasangkan dengan peubah apapun.

Setelah didapatkan hasil Analisis Komponen Utama, selanjutnya adalah mencari harga mutlak koefisien terbesar dari masing-masing peubah $Y_{i}$. Setelah melakukan proses Analisis Komponen Utama dan survei, didapatkan hasil seperti dibawah ini yaitu hubungan antara ciri wajah dengan indikator kemiskinan.

(1) Kelengkungan mulut

Persentase Kepala Rumah Tangga yang tamat SMA/sederajat $\left(X_{5}\right)$

(2) Kemiringan Alis

Persentase Rumah Tangga dengan kondisi kesejahteraan antara 11\%-20\% terendah $\left(X_{14}\right)$

(3) Tinggi Alis

Persentase Rumah Tangga dengan jenis lantai tanah $\left(X_{9}\right)$

(4) Posisi Pupil

Persentase Rumah Tangga dengan jenis atap seng $\left(X_{6}\right)$

(5) Kemiringan Mata

Persentase Rumah Tangga dengan kondisi kesejahteraan antara 21\%-30\% terendah $\left(X_{15}\right)$

(6) Bentuk Elips Mata

Persentase Kepala Rumah Tangga yang tamat SD/SMP sederajat $\left(X_{2}\right)$

(7) Panjang Mulut

Persentase Rumah Tangga dengan jenis atap ijuk/rumbai $\left(X_{7}\right)$

(8) Jarak Antar Mata

Persentase Rumah Tangga dengan dinding kayu $\left(X_{8}\right)$

(9) Panjang Hidung

Persentase Rumah Tangga yang tidak ada listrik $\left(X_{11}\right)$

(10) Posisi Pusat Mulut

Persentase Rumah Tangga dengan status penguasaan bangunan tempat tinggal kontrak/sewa $\left(X_{3}\right)$ 
(11) Tinggi Pusat Mata

Persentase Kepala Rumah Tangga yang tidak punya ijazah $\left(X_{1}\right)$

(12) Lebar Wajah

Persentase Rumah Tangga dengan sumber air minum dari air tak terlindung $\left(X_{10}\right)$

(13) Bentuk Elips Bawah Wajah

Persentase Rumah Tangga dengan fasilitas tempat BAB bersama/umum $\left(X_{12}\right)$

(14) Bentuk Elips Atas Wajah

Persentase Rumah Tangga dengan status penguasaan bangunan tempat tinggal milik sendiri $\left(X_{4}\right)$

(15) Panjang Alis

Persentase Rumah Tangga dengan kondisi kesejahteraan sampai dengan 10\% terendah $\left(X_{13}\right)$

Selanjutnya, indikator-indikator kemiskinan akan dibagi menjadi dua sifat, yaitu sifat indikator kemiskinan positif dan sifat indikator kemiskinan negatif. Indikator positif adalah suatu indikator dimana semakin besar nilai indikator tersebut maka semakin baik kondisi kecamatan, sedangkan indikator negatif adalah suatu indikator dimana semakin besar nilai indikator tersebut maka semakin buruk kondisi kecamatan. Hal ini berguna dalam menginterpretasikan ciri wajah Chernoff dan bertujuan untuk membuat wajah Chernoff yang benar.

\section{Sifat Indikator Positif}

(1) Persentase Kepala Rumah Tangga yang tamat SMA/sederajat.

(2) Persentase Rumah Tangga dengan status penguasaan bangunan tempat tinggal milik sendiri.

(3) Persentase Rumah Tangga dengan jenis atap seng.

\section{Sifat Indikator Negatif}

(1) Persentase Kepala Rumah Tangga yang tidak punya ijazah.

(2) Persentase Kepala Rumah Tangga yang tamat SD/SMP sederajat.

(3) Persentase Rumah Tangga dengan status penguasaan bangunan tempat tinggal kontrak/sewa.

(4) Persentase Rumah Tangga dengan jenis atap ijuk/rumbai.

(5) Persentase Rumah Tangga dengan dinding kayu.

(6) Persentase Rumah Tangga dengan jenis lantai tanah.

(7) Persentase Rumah Tangga dengan sumber air minum dari air tak terlindung.

(8) Persentase Rumah Tangga yang tidak ada listrik.

(9) Persentase Rumah Tangga dengan fasilitas tempat BAB bersama/umum.

(10) Persentase Rumah Tangga dengan kondisi kesejahteraan sampai dengan 10\% terendah.

(11) Persentase Rumah Tangga dengan kondisi kesejahteraan antara 21\%-30\% terendah.

(12) Persentase Rumah Tangga dengan kondisi kesejahteraan antara 11\%-20\% terendah. 
Berdasarkan hasil diatas, interpretasi terhadap wajah Chernoff dapat dilakukan dengan panduan sebagai berikut.

(1) Persentase Kepala Rumah Tangga yang tamat SMA/sederajat (positif) memiliki ciri wajah kelengkungan mulut dengan interpretasi Semakin lengkung mulut ke atas maka semakin besar persentase Kepala Rumah Tangga yang tamat SMA/sederajat.

(2) Persentase Rumah Tangga dengan kondisi kesejahteraan antara 11\%-20\% terendah (negatif) memiliki ciri wajah Kemiringan Alis dengan interpretasi Semakin naik alis maka semakin kecil persentase Rumah Tangga dengan kondisi kesejahteraan antara 11\%-20\% terendah.

(3) Persentase Rumah Tangga dengan jenis lantai tanah (negatif) memiliki ciri wajah Tinggi Alis dengan interpretasi Semakin tinggi alis maka semakin kecil persentase Rumah Tangga dengan jenis lantai tanah.

(4) Persentase Rumah Tangga dengan jenis atap seng (positif) memiliki ciri wajah Posisi Pupil dengan interpretasi Semakin ke kanan posisi pupil maka semakin besar persentase Rumah Tangga dengan jenis atap seng.

(5) Persentase Rumah Tangga dengan kondisi kesejahteraan antara 21\%-30\% terendah (negatif) memiliki ciri wajah Kemiringan Mata dengan interpretasi Semakin naik mata semakin kecil persentase Rumah Tangga dengan kondisi kesejahteraan antara 21\%-30\% terendah.

(6) Persentase Kepala Rumah Tangga yang tamat SD/SMP sederajat (negatif) memiliki ciri wajah Bentuk Elips Mata dengan interpretasi Semakin bulat bentuk mata maka semakin kecil persentase Kepala Rumah Tangga yang tamat SD/SMP sederajat.

(7) Persentase Rumah Tangga dengan jenis atap ijuk/rumbai (negatif) memiliki ciri wajah Panjang Mulut dengan interpretasi Semakin panjang mulut maka semakin kecil persentase Rumah Tangga dengan jenis atap ijuk/rumbai.

(8) Persentase Rumah Tangga dengan dinding kayu (negatif) memiliki ciri wajah Jarak Antar Mata dengan interpretasi Semakin panjang mulut maka semakin kecil persentase Rumah Tangga dengan dinding kayu.

(9) Persentase Rumah Tangga yang tidak ada listrik (negatif) memiliki ciri wajah Panjang Hidung dengan interpretasi Semakin panjang hidung maka semakin kecil persentase Rumah Tangga yang tidak ada listrik.

(10) Persentase Rumah Tangga dengan status penguasaan bangunan tempat tinggal kontrak/sewa (negatif) memiliki ciri wajah Posisi Pusat Mulut dengan interpretasi Semakin jauh pusat mulut dengan pusat wajah maka semakin kecil persentase Rumah Tangga dengan status penguasaan bangunan tempat tinggal kontrak/sewa.

(11) Persentase Kepala Rumah Tangga yang tidak punya ijazah (negatif) memiliki ciri wajah Tinggi Pusat Mata dengan interpretasi Semakin tinggi pusat mata maka semakin kecil persentase Kepala Rumah Tangga yang tidak punya ijazah.

(12) Persentase Rumah Tangga dengan sumber air minum dari air tak terlindung (negatif) memiliki ciri wajah Lebar Wajah dengan interpretasi Semakin lebar wajah maka semakin kecil persentase Rumah Tangga dengan sumber air 
minum dari air tak terlindung.

(13) Persentase Rumah Tangga dengan fasilitas tempat BAB bersama/umum (negatif) memiliki ciri wajah Bentuk Elips Bawah Wajah dengan interpretasi Semakin bulat bentuk elips bawah wajah maka semakin kecil persentase Rumah Tangga dengan fasilitas tempat BAB bersama/umum.

(14) Persentase Rumah Tangga dengan status penguasaan bangunan tempat tinggal milik sendiri (positif) memiliki ciri wajah Bentuk Elips Atas Wajah dengan interpretasi Semakin bulat bentuk elips atas wajah maka semakin besar persentase Rumah Tangga dengan status penguasaan bangunan tempat tinggal milik sendiri.

(15) Persentase Rumah Tangga dengan kondisi kesejahteraan sampai dengan 10\% terendah (negatif) memiliki ciri wajah Panjang Alis dengan interpretasi Semakin panjang alis maka semakin kecil persentase Rumah Tangga dengan kondisi kesejahteraan sampai dengan $10 \%$ terendah.

Untuk melihat potret kemiskinan tiap kecamatan Kota Padang, dilakukan perbandingan antara wajah Chernoff tiap kecamatan dengan wajah Chernoff rata-rata. Wajah Chernoff rata-rata adalah wajah Chernoff yang dibuat berdasarkan nilai default yang terdapat pada program Statistica 10.

Hasil wajah Chernoff masing-masing kecamatan di Kota Padang dapat dilihat pada Gambar 1.

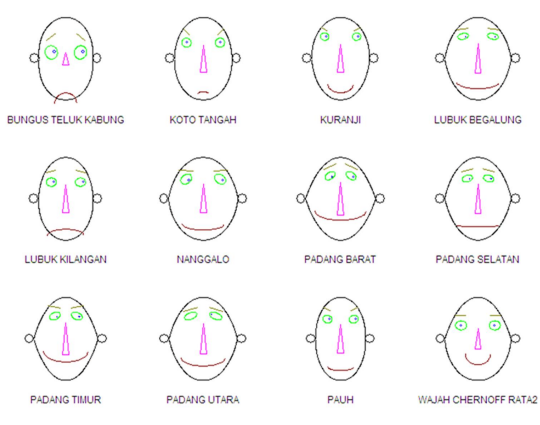

Gambar 1. Wajah Chernoff Masing-Masing Kecamatan

Dari Gambar 1, terdapat lima kandidat kecamatan dengan wajah Chernoff yang relatif bagus jika dibandingkan dengan wajah Chernoff lainnya yaitu kecamatan Padang Barat, kecamatan Padang Utara, kecamatan Nanggalo, kecamatan Lubuk Begalung, dan kecamatan Padang Timur.

Dari Gambar 1 juga terdapat empat kandidat kecamatan dengan wajah Cher- 
noff yang relatif tidak bagus jika dibandingkan dengan wajah Chernoff lainnya yaitu kecamatan Bungus Teluk Kabung, kecamatan Koto Tangah, kecamatan Lubuk Kilangan, dan kecamatan Padang Selatan.

Untuk melihat potret kemiskinan Kota Padang secara keseluruhan, maka juga dilakukan perbandingan antara wajah Chernoff Kota Padang dengan wajah Chernoff rata-rata. Hasil wajah Chernoff Kota Padang dan wajah Chernoff rata-rata dapat dilihat pada Gambar 2.

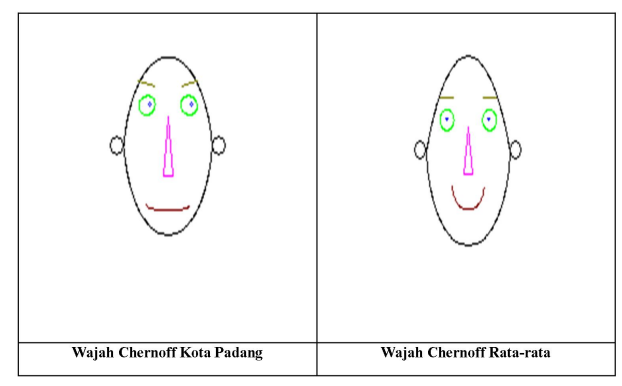

Gambar 2. Wajah Chernoff Rata-rata dan Wajah Chernoff Kota Padang

Dari Gambar 2 dapat dilihat indikator-indikator yang berada di bawah ratarata, di atas rata-rata, dan di sekitar rata-rata. Dari 15 indikator yang diamati, terdapat lima indikator di bawah rata-rata yaitu persentase Rumah Tangga dengan kondisi kesejahteraan antara 11\%-20\% terendah, persentase Rumah Tangga dengan jenis atap ijuk/rumbai, persentase kepala Rumah Tangga yang tidak punya ijazah, persentase Rumah Tangga yang tidak ada listrik, dan persentase Rumah Tangga dengan status penguasaan bangunan tempat tinggal kontrak/sewa; empat indikator di atas rata-rata yaitu persentase kepala Rumah Tangga yang tamat SMA/sederajat, persentase kepala Rumah Tangga yang tamat SD/SMP sederajat, persentase Rumah Tangga dengan dinding kayu, dan persentase Rumah Tangga dengan jenis atap seng; dan selainnya di sekitar rata-rata.

\section{Kesimpulan}

Berdasarkan hasil dan pembahasan dalam penelitian ini, dapat disimpulkan bahwa dari 15 indikator kemiskinan untuk Kota Padang, terdapat dua indikator, yaitu persentase kepala Rumah Tangga yang tamat SD/SMP sederajat dan persentase 
Rumah Tangga dengan dinding kayu, yang mempengaruhi tingkat kemiskinan, sehingga perlu diberikan perhatian khusus.

Berdasarkan hasil wajah Chernoff untuk masing-masing kecamatan di Kota Padang, terdapat empat kandidat kecamatan yaitu kecamatan Bungus Teluk Kabung, kecamatan Koto Tangah, kecamatan Lubuk Kilangan, dan kecamatan Padang Selatan, yang merupakan kecamatan dengan wajah Chernoff relatif tidak bagus, dan terdapat lima kandidat kecamatan yaitu kecamatan Padang Barat, kecamatan Padang Utara, kecamatan Nanggalo, kecamatan Lubuk Begalung, dan kecamatan Padang Timur, yang merupakan kecamatan dengan wajah Chernoff relatif bagus.

\section{Ucapan Terima Kasih}

Penulis mengucapkan terima kasih kepada Ibu Dr. Ferra Yanuar, Bapak Narwen, M.Si, dan Ibu Monika Rianti Helmi, M.Si yang telah memberikan masukan dan saran dalam penyempurnaan penulisan artikel ini.

\section{Daftar Pustaka}

[1] BPS. 2011. Indikator Kemiskinan Kota Padang. Padang : BPS Kota Padang

[2] BPS. 2012. Padang Dalam Angka. Padang: BPS Kota Padang

[3] Morris, C.J, D.S. Ebert and P. Rheingans. No Year. An Experimental Analysis of the Effectiveness of Features in Chernoff Faces. University of Maryland Baltimore Country 